$B$

J. bio-sci. 18: 99-103, 2010

ISSN 1023-8654

http://www.banglajol.info/index.php/JBS/index

\title{
ISOLATION AND CHARACTERIZATION OF ESCHERICHIA COLI IN READY-TO-EAT FOODS VENDED IN ISLAMIC UNIVERSITY, KUSHTIA
}

\author{
S Biswas, M A K Parvez ${ }^{* 1}$, M Shafiquzzaman, S Nahar ${ }^{1}$, M N Rahman ${ }^{2}$ \\ Department of Biotechnology and Genetic Engineering, Islamic University, Kushtia 7003, Bangladesh \\ ${ }^{1}$ Department of Microbiology, Jahangirnagar University, Savar, Dhaka and \\ 2Department of Biochemistry and Molecular Biology, Jahangirnagar University, Savar, Dhaka
}

\begin{abstract}
Context: Escherichia coli is shed in the feces of warm blooded animals and humans and thus potential for public health. Detection and characterization of $E$. coli in the ready-to-eat (RTE) foods concerns due to their presence indicates fecal contamination of the food.

Objective: To identify, characterize and RFLP pattern analysis of $E$. coli isolated from RTE foods vended in Islamic University campus, Kushtia.

Materials and Methods: Fifty samples from four types of consumed foods in six student halls of residence, some temporary restaurants of Islamic University, Kushtia were assessed for bacterial contamination by standard methods. Identification and characterization of $E$. coli isolates were performed using IMViC tests. Genomic DNA was used to perform RFLP pattern analysis

Results: Thirty seven out of $50(74 \%)$ examined samples of RTE foods had E. coli contamination. The highest number of $E$. coli was isolated from vegetable oriented RTE foods $(90.90 \%)$ and fish, meat and cereals samples were also significantly $E$. coli positive. RFLP profiling of two $E$. coli isolates were observed.

Conclusion: The results of this study provide evidence that some RTE foods had unsatisfactory levels of contamination with $E$. coli. Thus street vended RTE food could be important potential vehicles for food-borne diseases. Molecular characterization may be exploited to identify food borne pathogen among different species.
\end{abstract}

Keywords: Ready-to-eat foods, Escherichia coli, RFLP pattern.

\section{Introduction}

Food safety is an important part of public health, linking health to agricultural and other food production sectors (Schlundt 2002). Besides human sufferings and fatalities, the highest number of food borne outbreaks in recent years has devastating economic impact on food producer and processors. In addition, previously unknown food borne pathogens are constantly emerging (Newell et al. 2010) which are responsible for increased incidence of food borne diseases. These observations refer to street-vended foods. Familiarity, taste, low-cost and convenience are some of the appealing factors that make street foods popular as food source (Hanashiro et al. 2005). The street food industry plays an important role in developing countries (Muinde and Kuria 2005). Because of socioeconomic changes in many countries, this sector has experienced significant growth during the past few decades. They feed millions of people daily with a wide variety of ready-to-eat (RTE) foods and beverages sold and sometimes prepared in the streets or public places, relatively cheap and easily accessible (Barro et al. 2002).

The role of street food vendors in the transmission of diarrhoeal pathogens has been well-reported (Bryan et al. 1988). In Bangladesh, the presence of any pathogenic organisms in RTE food is a serious public health concern, as they do not receive any further treatment before consumption. Among bacteria, Clostridium botulinum, Escherichia coli, Salmonella spp., Listeria monocytogens, Yersinia enterocolitica, Staphylococcus aureus, Shigella spp., Bacillus cereus and Campylobacter jejuni comprise major part of food borne

* Corresponding author E-mail: khasru1973@yahoo.com 
pathogens (Kumar et al. 2002). There is few data concerning the incidence of food borne diseases related to street foods in Bangladesh.

Among all food borne pathogen E. coli received much more attention. E. coli, a common inhabitant of the intestinal tract of humans and animals (Tannock 1995, Sørum and Sunde 2001), can be easily disseminated in different ecosystems through water supplies and the food chain (Perreten 2005). In addition, this microorganism can be implicated in human infections, mainly in immune-compromised patients (Huang et al. 2006) or when gastrointestinal barriers are violated, even normal 'nonpathogenic' strains of $E$. coli can cause infection.

About $98 \%$ of microbes found in food commodities are non-pathogenic (Kumar et al. 2002). Therefore it is necessary to characterize the target pathogen in order to develop a suitable diagnostic test to detect them. The conventional method to detect food borne pathogen is culturing technique, which include homogenization of food sample and enrichment in selective and nonselective media by plating to isolate pure culture. Finally phenotypic and genotypic characterization takes 3-4 days to confirm the results. Immunological and biochemical detection are time consuming; require pure culture and less sensitive over molecular method. DNA based method can deploy within mix culture of bacteria. Variation of DNA polymorphism among different bacterial species may exploit to identify food borne pathogen.

Therefore, the objective of this study was to determine the occurrence of $E$. coli in different types of RTE food samples collected from Islamic University campus, Kushtia, and to observe RFLP pattern.

\section{Materials and Methods}

Sample collection: Approximately $300 \mathrm{~g}$ of each fifty samples of RTE food of 4 categories (22 samples of cereals, 10 samples of meat, 7 samples of fish and 11 samples of vegetables) were collected between April 2009 and July 2009 from 6 student halls of residence and some temporary restaurants of Islamic university campus, Kushtia, Bangladesh. All samples were transported in sterile container to the laboratory and were tested within $24 \mathrm{~h}$ of collection. Ten grams of each food sample was mixed with one eighth strength Ringers Solution (Oxoid, Basingstoke, UK). The sample was homogenized with a blender (electric) at $6000 \mathrm{rpm}$ for 510 minutes (10-1 dilution), followed by serial dilutions up to $10^{-6}$ dilution.

Standard coliform test and isolation of $E$. coli: Coliform counts were determined using the most probable number (MPN) method (Cappuccino and Sherman 1999, Harley and Prescott 2002). Fermentation tubes with appropriate quantity $(10 \mathrm{ml})$ of lauryl tryptose broth medium were distributed with different strengths. The tubes were inoculated with $10 \mathrm{ml}, 1 \mathrm{ml}$ with $10 \mathrm{ml}$, and $1 \mathrm{ml}$ and $0.1 \mathrm{ml}$ amount of sample and incubated at $37^{\circ} \mathrm{C}$ for $24 \mathrm{~h}$. All tubes of the presumptive test producing gas after $24 \mathrm{~h}$ of incubation, was further tested for conformation. A loopful inoculum from each culture showing production of acid and gas was transferred to Brilliant Green Bile Broth (Oxoid) and incubated for $48 \mathrm{~h}$ at $37^{\circ} \mathrm{C}$ and $44.5^{\circ} \mathrm{C}$. Gas production at $44.5^{\circ} \mathrm{C}$ confirms presence of fecal coliform. Streaking on the eosine methylene blue (EMB) agar plate was done for further confirmation that was performed according to Cappuccino and Sherman (1999). One or more plates containing EMB agar medium were streaked from presumptive positive test tubes in such a way that discrete colonies may appear. The plates were incubated at $37^{\circ} \mathrm{C}$ for $24 \mathrm{~h}$. Typical nucleated colonies with or without metallic sheen indicates positive results. A maximum of five suspected $E$. coli colonies from each sample (based on colony size, morphology and metallic green sheen on their surfaces) were selected. Further biochemical tests were done for the identification of Escherichia coli according to Cappuccino and Sherman (1999) and Coyle et al. (1985). IMViC test was performed to distinguish between E. coli and Enterobacter aerogenes (Cappuccino and Sherman 1999). Two isolates identified as E. coli were further characterized based on DNA polymorphism by RFLP. 
Genomic DNA extraction: Standard and improved phenol chloroform method was used to extract genomic DNA (Neumann et al. 1992) with a few changes. Different samples were pre-treated properly for the collection of organism cell. In regard to pure bacteria culture, $1.4 \mathrm{ml}$ bacteria suspension was collected by centrifugation at $16.1 \mathrm{rcf}$ for $10 \mathrm{~min}$ at $4^{\circ} \mathrm{C}$; precipitation was mixed well with $0.4 \mathrm{ml} \mathrm{TE}\left(10 \mathrm{mmol}^{-1} \mathrm{Tris}-\mathrm{HCl}, 1\right.$ mmol- EDTA, and pH 8.0). After adding $50 \mu \mathrm{l}$ of $10 \%$ SDS and $50 \mu \mathrm{l}$ proteinase $\mathrm{K}$, pellete was incubated at $42^{\circ} \mathrm{C}$ for $20 \mathrm{~min}$ in water bath. All nucleic acid came out of solution soon after adding $0.15 \mathrm{ml}$ of $5 \mathrm{M} \mathrm{NaCl}$ and $0.25 \mathrm{ml}$ of ice cold isopropanol. The supernatant was transferred to a new tube and $0.7 \mathrm{vol}$ of phenol/chloroform (1: 1) was added. After gentle mixing, the mixture was centrifuged at $16.1 \mathrm{rcf}$ for $10 \mathrm{~min}$ at $4^{\circ} \mathrm{C}$. The upper phase was transferred to a new tube containing $2 / 3$ vol of isopropanol. The mixture was cooled at $-20^{\circ} \mathrm{C}$ for $30 \mathrm{~min}$ and then centrifuged at $16.1 \mathrm{rcf}$ for $10 \mathrm{~min}$ at $4^{\circ} \mathrm{C}$. The resulting pellet was dissolved with $100 \mu \mathrm{l} \mathrm{TE}$ buffer after washing twice with $70 \%$ ice cold ethanol. The quantity and quality of the purified DNA were determined by measuring at A260 and by calculating the ratio of A260/A280, respectively by spectrophotometer. Finally, agarose gel electrophoresis of extracted DNA was performed using $0.8 \%$ UltraPureTM agarose (Invitrogen).

Restriction analysis: To get total $20 \mu$ of volume, $1 \mu$ of genomic DNA was mixed with $15 \mu$ l of distilled water and $2 \mu \mathrm{l}$ of enzyme-assay buffer and finally with $2 \mu \mathrm{l}$ of restriction enzyme (GeNei TM) i.e. BamHI (10

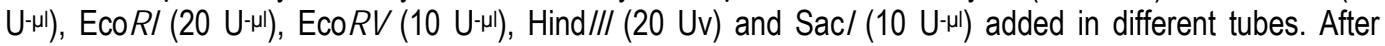
incubation for $1 \mathrm{~h}$ at $37^{\circ} \mathrm{C}$, complete digestion was checked on $3 \%$ agarose gel with using $100 \mathrm{bp}-1 \mathrm{~kb}$ reference ladders.

\section{Results}

E. coli was isolated from 37 out of $50(74 \%)$ food samples analyzed in this study; no $E$. coli isolates were obtained from the remaining 13 samples (including 7 samples of elaborated products derived from cereals). E. coli was detected in 10 out of $11(90.90 \%)$ vegetables oriented RTE foods. All other examined fish ( 5 out of 7), meat (7 out of 10) and cereals (15 out of 22) RTE samples were significantly $71.42 \%, 70 \%$ and $68.18 \%$ contaminated with $E$. coli respectively.

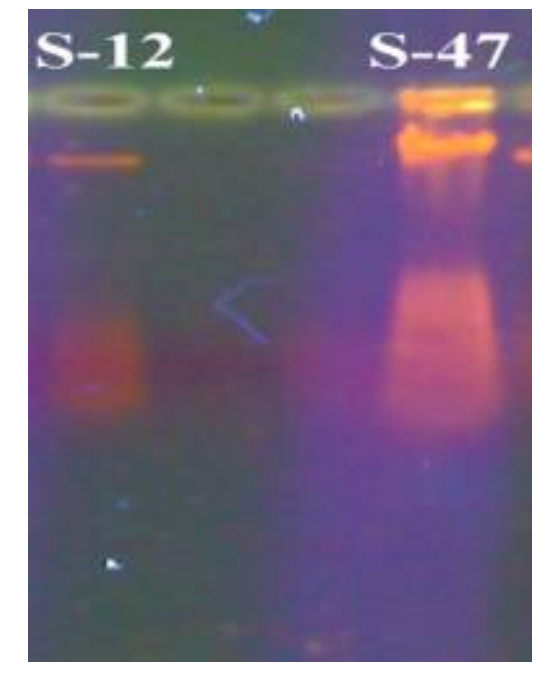

Fig. 1. Agarose gel electrophoresis pattern of the extracted DNA

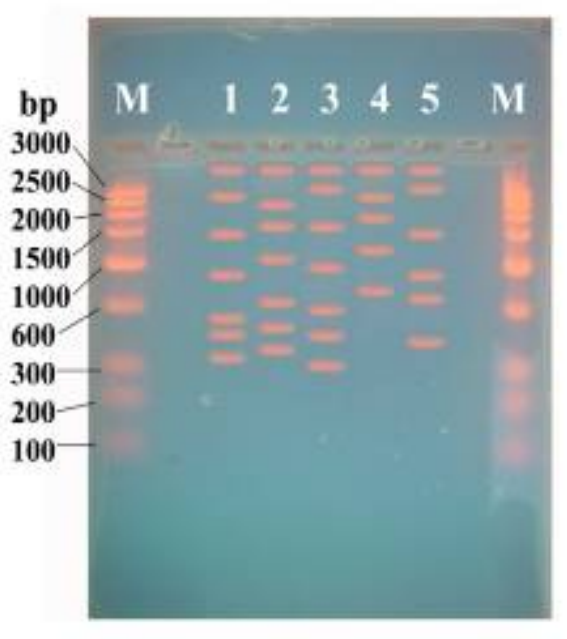

Fig. 2. RFLP pattern of one sample after electrophoresis. Lane1:BamHI, lane2:EcoRI, lane3: EcoRV, lane4:HINDIII, lane5: Sacl 
High yield genomic DNA extracted from two E. coli samples was obtained in present study. The A260 value of two DNA sample was 1.8199 and 1.7968 . The A260/A280 ratio was 1.943 and 1.86 respectively. Some manipulations in the phenol/chloroform procedure were done. These were the addition of $\mathrm{NaCl}$ solution and ice cold isopropanol before phenol: chloroform extraction of samples. These two steps boosted the yield of high-quantity and high-quality genomic DNA and was amenable to further molecular characterization with RFLP. The integrity of the extracted DNA and restriction fragment pattern was checked by agarose gel electrophoresis (Figs. 1 and 2). The size of most digested DNA fragments ranged from 300 to 3000 bp (Fig. 2). RFLP digestion pattern might be the more powerful marker for molecular detection of pathogenic organism if coupled with PCR (e.g. RT-PCR). PCR amplification of the target gene with the appropriate oligonucleotide primer would be very specific for target organism. In future, the target gene of $E$. coli could be amplified and sequencing of the gene could reveal the better understanding of pathogenicity.

\section{Discussion}

A number of reports published on $E$. coli contamination of food. $E$ coli contamination (6.34\%) was observed among 101 cooked and prepared food in a University centre in Argentina (Tessi et al. 2002). Another study conducted in Bangkok showed that coliform bacteria present in more than 50 percent of the food samples (Dawson et al. 1996). In the present study $74 \%$ food sample found as $E$. coli positive. The frequency of $E$. coli was found to be highest in vegetables. In Korea, $E$. coli was most frequently detected in convenient foods and $50 \%$ samples were found to be E. coli contaminated (Chung et al. 2010). Coliforms might be appeared in every phase of preparation; a case was reported (Seo et al. 2010) during investigation of the microbial quality of cooked soybean sprout salad. Presence of coliforms and $E$. coli in food may indicate fecal contamination which might be due to insufficient cooking, use of raw vegetables, cross contamination between raw and cooked food and contaminated ingredients (Eley 1992). So, presence of $E$. coli in $74 \%$ RTE food samples in the present study might be representing fecal contamination. People who depend on such food are often more interested in its convenience than in questions of its safety, quality and hygiene. Pathogenic bacteria including S. aureus, E. coli and Salmonella in restaurants would transfer to the cooked foods by contaminated staffs' hands or dishes (Nichols et al. 2002).

In our previous work, we reported that street foods in Dhaka city were extremely contaminated with microorganisms at an unacceptable limit especially the raw vendor items (Shaik et al. 2010). Total coliform was found to be present in all samples, indicating an alarming situation of health hazard. Bangladesh is an endemic zone for diarrhoeal diseases: every year, more than $5 \%$ of death of children below 5 years of age is attributed to diarrhea (Arifeen et al. 2005). In Bangladesh, the predominant group of $E$. coli, associated with childhood diarrhea is ETEC, accounting for approximately $20 \%$ of all diarrhoeal cases (Qadri et al. 2005)

\section{Conclusion}

RTE foods vended in Islamic University campus, Kushtia had unsatisfactory levels of contamination with $E$. coli. Unhygienic practice may reveal the risk factors associated with contamination of post processing food. Food-borne disease is an urgent public health problem and requires raid intervention. RFLP pattern analysis might be useful for molecular detection of pathogenic organism among different species if coupled with PCR. However, further detailed scientific study is necessary to develop rapid and easy detection method of pathogenic organism in food.

\section{References}

Arifeen SE, Akhter T, Chowdhury HR, Rahman KM, Chowdhury EK. 2005. Causes of death in children under five years of age. In: National Institute of Population Research and Training. 125-133 pp.

Barro N, Nikiéma P, Ouattara CAT, Traoré AS. 2002. Evaluation de l'hygiène et de la qualité microbiologique de quelques aliments rue et les caractéristiques des consommateurs dans les villes de Ouagadougou et de Bobo-Dioulasso (Burkina Faso). Rev Sci Tec Sci Santé 25, 7-21. 
Bryan FL, Michanie SC, Alvarez P, Paniagua A. 1988. Critical control points of street-vended foods in the Dominican Republic. J Food Prot 51, 373-383.

Cappuccino JG, Shermam N. 1999. Microbiology: A Laboratory Manual. Fourth The Benjamin/Cummins Publishing Company Inc California USA.

Chung M, Kim C, Ha S. 2010. Detection and enumeration of microorganisms in ready-to-eat foods, ready-to-cook foods and fresh-cut produce in Korea. J Food Safety 30(2), 480-489. http://dx.doi:10.1111/j.1745-4565.2010.00221.x

Coyle MB, Morello JA, Smith PB. 1985. Aerobic bacteria. In: Lennette EH, Balow A, Housler WJ, Shadomy HJ (eds) Manual of Clinical Microbiology. American Society for Microbiology, Washington DC, USA, 143-411pp.

Dawson R, Liamrandsi S, Boccas F. 1996. Bangkok's Street Food Project. Food, Nutrition and Agriculture / Alimentation Nutrition and Agriculture. FAO Publication 17/18.

Eley AR. 1996. Toxic bacterial food poisoning. In: Eley A.R (ed) Microbial Food Poisoning. 2nd ed. London: Chapman and Hall. pp. 47

Hanashiro A, Morita M, Matté GR, Matté, MH, Torres EAFS. 2005. Microbiological quality of selected street foods from a restricted area of Säo Paulo city, Brazil. Food Control 16, 439-444. http://dx.doi:10.1016/j.foodcont.2004.05.004

Harley JP, Prescott LM. 2002. Laboratory Exercises in Microbiology, Fifth Edition The McGraw-Hill Companies,

Huang DB, Mohanty A, DuPont HL, Okhuysen PC, Chiang T. 2006. A review of an emerging enteric pathogen: enteroaggregative Escherichia coli. J Med Microbiol 55, 1303-1311.

Kumar SH, Iddya K, Karunasagar I. 2002. Molecular methods for rapid and specific detection of pathogens in seafood. Aquacult Asia 3 , 34-37.

Muinde OK, Kuria E. 2005. Hygenic and sanitary practices of vendors of street foods in Nairobi, Kenya. AJFAND online www.ajfand.net: 5, 1-13.

Neumann B, Pospiech A, Schairrer HU. 1992. Rapid isolation of genomic DNA from Gram-negative bacteria. Trends Genet 8, 332-333.

Newell DG, Koopmans M, Verhoef L, Duizer E, Aidara-Kane A, Sprong H, Opstegh M, Langelaar M, Threfall J. Scheutz F, Vander Giessen J, Kruse H. 2010. Food-borne disease the challenges of 20 years ago still persist while new ones continue to immerge. Int J Food Microbiol 30, S3-S15. http://dx.doi:10.1016/j.ijfoodmicro.2010.01.021 PMid:20153070

Nichols GL, Little CL, Mithani V, Louvois J. 2002. Microbiological quality of take-away cooked rice and chicken sandwiches: effectiveness of food hygiene training of the management. J Food Protect 62(8), 877-882.

Perreten V. 2005. Resistance in the food chain in bacteria from animals: relevance to human infections, In White DG, Alekshun MN, McDermont PF (eds) Frontiers in antimicrobial resistance. ASM Press, Washington, DC. 446-464pp.

Qadri F, Svennerholm AM, Faruque AS, Sack RB. 2005. Enterotoxigenic Escherichia coli in developing countries: epidemiology, microbiology, clinical features, treatment and prevention. Clin Microbiol Rev 18, 465-483. http://dx.doi:10.1128/ CMR.18.3.465483.2005 PMid:16020685 PMCid:1195967

Schlundt J. 2002. New directions in food borne disease prevention. Int J Food Microbiol 78, 3-17. http://dx.doi:10.1016/S01681605(02)00234-9

Seo S, Seo H, Cha M, Oh M. 2010. Microbiological analysis of cooked bean sprout salad consumed in Korea. J Food Safety 30(2), $415-431$.

Shaik MM, Rahman S, Khaton MM, Parvez MA. 2010. Microbiological quality of popularly consumed street foods in Dhaka. BJMS 16(01), 81-83.

Sørum H, Sunde M. 2001. Resistance to antibiotics in the normal flora of animals. Vet Res 32, 227-241. http://dx.doi:10.1051/ vetres:2001121 PMid:11432415

Tannock GW. 1995. Normal microflora. An introduction to microbes inhabiting the human body. Chapman and Hall, London.

Tessi MA, Aringoli EE, Pirovani ME, Vincenzini AZ, Sabbag NG, Costa SC. 2002. Microbiological quality and safety of ready-to-eat cooked foods from a centralized school kitchen in Argentina. J Food Prot 65(4), 636-642. PMid:11952212 